Available at http://jurnal.utu.ac.id/JNS/article/view/2251

\title{
Factors Related with Anemia in Pregnant Women in in Johan Pahlawan Sub-District West Aceh District
}

\author{
${ }^{1}$ Susy Sriwahyuni, ${ }^{2}$ Fitriani Fitriani, ${ }^{3}$ Azwar Azwar \\ ${ }^{1}$ Public Health Faculty, Teuku Umar University, Indonesia, susysriwahyuni@utu.ac.id \\ ${ }^{2}$ Public Health Faculty, Teuku Umar University, Indonesia, fitriani@utu.ac.id \\ ${ }^{3}$ Public Health Faculty, Teuku Umar University, Indonesia, azwar@utu.ac.id \\ Coresponding author : Susy Sriwahyuni, e-mail : susysriwahyuni@utu.ac.id
}

\begin{abstract}
Anemia in Pregnant Women is a health problem during pregnancy. Where the state of decreased hemoglobin levels and the number of red blood cells below normal values. Increased need for iron nearly tripled for the needs of mothers and fetuses during pregnancy, anemia in pregnant women has an impact on morbidity and maternal death, the risk of low birth weight, premature birth. Anemia can also be avoided by consuming foods that often contain animal protein and vegetable protein. Iron (Fe) intake, knowledge, and family support have an important role in the incidence of anemia in pregnancy. This type of research is a cross sectional survey. The study was conducted in Johan Pahlawan Sub-district, West Aceh District. The population is all pregnant women trimester II and III of 54 pregnant women. Taking in total sampling, data analysis used Univariate analysis and Bivariate (Chi-Square test). The results of the study obtained a relationship between the knowledge factor with the P-value $=0.001$ and the Family Support factor with a P-value $=0.004$ with the incidence of anemia in pregnant women. Expected mothers are expected to know the importance of consuming iron $(\mathrm{Fe})$ intake, extensive knowledge about the dangers of anemia during pregnancy and the importance of family support for pregnant women to avoid anemia.
\end{abstract}

How to cite this article: Sriwahyuni, S., Fitriani, F., Azwar, A. (2020). Factors Related with Anemia in Pregnant Women in Johan Pahlawan Sub-District West Aceh District. JNS : Journal of Nutrition Science, 1(1), 14-18.

\section{Introduction}

Anemia is a condition of hemoglobin levels in the blood of pregnant women unable to meet the oxygen needs needed by the body. The standard for setting anemia varies between groups, in women of childbearing age $<12.0 \mathrm{~g} / \mathrm{dl}$ it is said to be anemia, whereas in pregnant women it is said to be anemia if $\mathrm{Hb}<11.0 \mathrm{~g} / \mathrm{dL}$ (Ministry of Health Republic of Indonesia, 2014). Anemia can increase mortality, especially in pregnant women and children (Ningrum, 2016). Pregnant women with anemia will increasing the risk of low birth weight babies, fetal death and premature babies. In addition, anemia can also increase the risk of bleeding, hypertension

\section{ARTICLE INFORMATION}

Submitted: $14 / 01 / 2020$

Revised: 16/02/2020

Accepted: 21/04/2020

Published Online : 15/05/2020

Keywords:

Knowledge

Family

Support

Anemia during pregnancy, and heart abnormalities in pregnant women (Anggraeni, 2014).

The four main nutritional problems in Indonesia are Iodine Deficiency Disorders (IDD), Vitamin A Deficiency (VAD), Chronic Energy Deficiency (KEK), and iron nutrient anemia (AGB). Problems that often occur in adolescents and pregnant women are anemia, iron deficiency, and excess or underweight (Sulistyoningsih, 2016).

Anemia in pregnancy is a condition of the hemoglobin $(\mathrm{Hb})$ level $<11 \mathrm{gr} \%$ in the first and third trimesters while in the third trimester while in the second trimester hemoglobin levels $<10.5 \mathrm{gr} \%$. Pregnancy anemia is called "potentional danger to 
mother and child", that's why anemia needed serious attention from all parties involved in health care (Manuaba, 2015). The causes of anemia in pregnant women is iron deficiency in the body. Iron deficiency anemia is anemia caused by lack of iron, folic acid and vitamin B12 due to inadequate intake or low availability of iron. (Brown LS, 2015).

Anemia in pregnant women often occurs due to physiological changes during pregnancy and is not offset by nutritious food intake and low consumption of iron-supplementing tablets intended for pregnant women (Sinaga, 2017) in 2017, around $83 \%$ of pregnant women have consumed $\mathrm{Fe} 3$ iron tablets provided by the government, but that still does not meet the targets that have been set, namely> 92\% of pregnant women (Lampung Provincial Health Office, 2018).

Anemia can occur due to nutrient deficiencies which have the role of forming hemoglobin such as iron, protein, pyridoxine, vitamin $\mathrm{E}$, folic acid, vitamin B12 and vitamin C. Vitamin C plays a role in the absorption and release of iron from transferrin to tissues. Folic acid functions in the metabolism of amino acids needed when the formation of red blood cells and white blood cells. Vitamin B12 functions to activate folic acid, while vitamin $\mathrm{E}$ for cell stabilization (Setyawati and Syauqy, 2014).

Iron is the most abundant micro mineral in the body. Iron has a function to transport oxygen, capture electrons in cells, and as part of enzyme reactions in tissues (Almatsier, 2010). Iron absorption is influenced by many factors. For example animal protein and vitamin $\mathrm{C}$ can increase absorption, while coffee, tea, salt, calcium, magnesium can bind iron so that the absorption process is reduced (Arisman, 2016).

Iron and pyridoxine proteins function as catalysts for heme synthesis. Protein plays a role in transporting iron to make new hemoglobin in the bone marrow (Setyawati and Syauqy, 2014). About 95\% of cases of anemia during pregnancy are due to iron deficiency. Family income is the cause of poor consumption patterns, not all people can consume animal side dishes in food. Diversity in food consumption plays an important role in helping increase the absorption of $\mathrm{Fe}$ in the body. Knowledge and education that a mother has will influence the decision making in providing adequate nutrition for mother and baby and more easily receive information so that it can prevent and overcome anemia during pregnancy. (Kristiyanasari, 2014)
Data from the World Health Organization (WHO) states that $40 \%$ of causes of maternal death in developing countries are related to anemia in pregnancy. Anemia in pregnancy is a major health problem in developing countries with high levels of illness in pregnant women. Total anemia sufferers in pregnant women in Indonesia is $70 \%$ meaning that of 10 pregnant women, 7 pregnant women will suffer from anemia. According to basic anemia health research data in 2014, the prevalence of anemia in pregnant women in Indonesia by $37 \%$ has increased from 2012 by $24.5 \%$ (Ministry of Health Republic of Indonesia, 2016).

Based on data from Riskesdas Indonesia in 2018, it showed that in 2013. Pregnant women who experienced anemia were $37.1 \%$, while in 2018 an increase of $48.9 \%$. While pregnant women according to age 15-24 years amounted to $84.6 \%$. While mothers with age $25-34 \%$ amounted to $33.7 \%$. And mothers aged 35-44 years amounted to $33.6 \%$. And mothers aged $45-54$ years as much as $24 \%$.

Based on the 2016 Aceh Health Office Data, the number of pregnant women are 117,923 (Aceh Health Office, 2016). in 2017 the number of pregnant women was 128,525 . And Based on data from the 2017 Aceh Health Office states that in 2015 mothers who received coverage of FE3 tablets amounted to $77 \%$, whereas in 2016 amounted to $72 \%$, and in 2017 an increase of $78 \%$.

Data pregnant women from the West Aceh Health Office in 2017 are 4.645 aand The f pregnant women who have anemia are 2219, (West Aceh Health Office, 2017). And in 2018 the number of pregnant women is 4758 . And pregnant women who have anemia 1675, (West Aceh Health Office, 2018). and in 2019 the number of pregnant women up to September is 4758 and the number of pregnant women who have anemia is 734 pregnant women, (West Aceh Health Office, 2019). And according to data from the Health Office of West Aceh in 2019, the highest number of pregnant women experiencing anemia.

According to a report from the Johan Pahlawan Community Sub-district in 2017, there were 1,086 pregnant women, 1,039 who visited the first visit, and 858 who visited 858. In 2018 there were 1,090 pregnant women. there were 1,000 first visits and 851 fourth visits. And in 2019 there were 1,090 pregnant women. there were 1,604 first visits and 748 visits. And there were 124 pregnant women still detected as pregnant, with 70 pregnant women 
in the first trimester, 39 pregnant women in the second trimester, and 39 in the third trimester 15 Pregnant women.

Based on an initial survey conducted by researchers in the working area of the Johan Pahlawan Sub-district in West Aceh District of 6 pregnant women who visited the Johan Pahlawan Sub-district, the results of interviews with 2 pregnant women stated that mothers do not always consume iron $(\mathrm{Fe})$ regularly because they forget and afraid to consume too much iron $(\mathrm{Fe})$ so the mother has anemia. Next 3 mothers stated that the mother did not know about the causes of anemia during pregnancy so the mother did not know how to prevent it. Then 1 mother stated that she did not often check her contents to the puskesmas, sometimes once every 2 months or 3 months because no family wanted or could not take the mother to the puskesmas so that the mother did not often get vitamins or iron (Fe) so she had anemia. during pregnancy.

The problem of anemia in pregnant women is still a serious problem in Johan Pahlawan Subdistrict with a variety of causes. Therefore, researcher interested in further researching the Relationship between Mother's Knowledge and Family Support for Anemia in Pregnant Women in Johan Pahlawan Sub-district, West Aceh District.

\section{Method}

This research is quantitative with Cross Sectional approach and analysis using univariate and bivariate analysis with chi-square test. The population of research are 54 pregnant women in II and III trimesters with a total sampling technique, which is taking all members of the population, as many as 54 respondents. This research was carried out in February 2019 in Johan Pahlawan Sub-district in West Aceh Regency.

\section{Results \\ Univariate Analysis}

Table 1. Characteristics of Respondents

\begin{tabular}{ll}
\hline Basic Characteristics & n (f\%) \\
\hline Age & $1(1,9 \%)$ \\
$16-20$ & $12(22,2 \%)$ \\
$21-25$ & $23(42,6 \%)$ \\
$26-30$ & $15(27,8 \%)$ \\
$31-35$ & $3(5,6 \%)$ \\
$36-40$ & \\
Education & $13(24,1 \%)$ \\
Elementary school & $15(27,8 \%)$ \\
Middle School & $23(42,6 \%)$ \\
High school & $3(5,6 \%)$ \\
College & \\
Pregnancy Trimester & $38(70,4 \%)$ \\
Trimester 2 & $16(29,6 \%)$ \\
Trimester 3 & \\
Knowledge & $37(68,5 \%)$ \\
Good & $17(31,5 \%)$ \\
Not good & \\
Family Support & $20(37 \%)$ \\
Good & $34(63 \%)$ \\
Not good & $24(44,4 \%)$ \\
Anemia in Pregnant Women & \\
There is & $30(55,6 \%)$ \\
There is no &
\end{tabular}

Bivariate Analysis

Table 7. Relationship between Mother's Knowledge and Anemia in Pregnant Women

\begin{tabular}{|c|c|c|c|c|c|c|c|c|}
\hline \multirow{3}{*}{ Knowledge } & \multicolumn{4}{|c|}{ Anemia in Pregnant Women } & \multirow{2}{*}{\multicolumn{2}{|c|}{ Total }} & \multirow{3}{*}{$\mathbf{P}_{\text {value }}$} & \multirow{3}{*}{$\begin{array}{c}\text { Rasio } \\
\text { Prevalance } \\
\text { ( CI 95\%) }\end{array}$} \\
\hline & \multicolumn{2}{|c|}{ There is no } & \multicolumn{2}{|c|}{ There is } & & & & \\
\hline & $\mathbf{f}$ & $\%$ & f & $\%$ & f & $\%$ & & \\
\hline Not Good & 8 & 47,1 & 9 & 52,9 & 17 & 100 & 0.001 & 606 \\
\hline Good & 22 & 59,5 & 15 & 40,5 & 37 & 100 & 0.001 & 606 \\
\hline
\end{tabular}

Based on the table can be seen that from 17 mothers who have poor knowledge that there is no anemia as many as 8 Mothers $(47.1 \%)$ and those who have anemia as many as 9 Mothers (52.9\%). Conversely from 37 mothers who have good knowledge as many as 15 Mothers ( 40.5\%) who have anemia. And those who do not have anemia are 22 mothers (59.5\%). The Pvalue from the chi-square test $=0.001<\alpha=0,05$ there is a relationship between mother's knowledge with anemia in pregnant women at Johan Pahlawan Sub-district, and the Prevalence Ratio (PR) is 606, it can be concluded that mothers who have good knowledge have the opportunity to avoid anemia by 606 times compared to mothers whose knowledge is not good. 
Table 8. Relationship of Family Support with Anemia in Pregnant Women

\begin{tabular}{|c|c|c|c|c|c|c|c|c|}
\hline \multirow{3}{*}{ Family Support } & \multicolumn{4}{|c|}{ Anemia in Pregnant Women } & \multirow{2}{*}{\multicolumn{2}{|c|}{ Total }} & \multirow{3}{*}{$\mathbf{P}_{\text {value }}$} & \multirow{3}{*}{$\begin{array}{c}\text { Rasio } \\
\text { Prevalance } \\
\text { ( CI 95\%) }\end{array}$} \\
\hline & \multicolumn{2}{|c|}{ There is no } & \multicolumn{2}{|c|}{ There is } & & & & \\
\hline & $\mathbf{f}$ & $\%$ & $\mathbf{f}$ & $\%$ & $\mathbf{f}$ & $\%$ & & \\
\hline Not Good & 16 & 47,1 & 18 & 52,9 & 34 & 100 & & \\
\hline Good & 14 & 70,0 & 6 & 30,0 & 20 & 100 & 0.004 & 381 \\
\hline
\end{tabular}

Based on the above table it can be seen that from 34 numbers of mothers whose family support is not good that there is no anemia as many as 16 people $(47.1 \%)$ and those who have anemia as many as 18 people $(52.9 \%)$. While out of the 20 mothers with good family support who did not have anemia, 14 people $(70.0 \%)$ and 6 people $(30.0 \%)$ had anemia.

The Pvalue from chi square test $=0.004<\alpha=$ 0.05 , there is a relationship between family support with anemia in pregnant women. the Prevalence Ratio (PR) 381, it mean that mother's who have good Family Support have an opportunity to avoid anemia by 381 times compared to mothers whose Support is not good.

\section{Discussion \\ Relationship between Knowledge and Anemia in Pregnant Women}

Resulth chi-square test show there is a relationship between Mothers's Knowledge and Anemia in pregnant women in Johan Pahlawan Subdistrict. The Prevalence Ratio is 606, it means that the respondent's knowledge has a strong chance that is 606 times with the incidence of anemia in pregnant women in the work area of the Johan Pahlawan Subdistrict.

Based on observations made by researchers in the field of mothers who have good knowledge more who do not have anemia compared to mothers who have poor knowledge. Broadly speaking according to (Notoadmodjo, 2014) Domain level of knowledge has six levels: knowing, understanding, using outlining, inferring and evaluating. The main characteristic in the level of knowledge is the memory of something that is known either through experience, learning, or information received from others.

Good knowledge will make pregnant women behave well too so that the prevention of anemia during pregnancy is effective. (Purulinawati. 2014).

The results of this study is line with research by Nila Eza Fitria (2018) stating that there is a relationship between knowledge and the incidence of anemia in pregnant women in Jorong Koto Malintong, Agam Regency (2018) with the results of the chi square test with a value of 0.002 which is smaller of $\alpha=0.05$ from this it can be concluded in this study there is a relationship between maternal knowledge with the incidence of anemia in pregnant women.

\section{Relationship between Family Support and Anemia in Pregnant Women}

Chi square test result show relationship between Family Support and Anemia in pregnant women in Johan Pahlawan Sub-district. The Prevalence Ratio 381, it means that the respondent's Family Support has a strong chance that is as much as 381 times the incidence of anemia in pregnant women in the work area of the Johan Pahlawan Subdistrict. Based on observations made by researchers in the field of mothers who have good family support more anemia than compared to mothers who support family is not good.

Pregnant women are in need of family support so families also need to get enough knowledge to do tasks in the family. Family tasks to get clear knowledge about pregnancy issues. Family support during pregnancy helps the pregnancy process and prevents complications during pregnancy such as iron deficiency anemia. Family support is also very important during pregnancy as it helps provide a varied, nutritious and balanced diet (Andramoyo, 2016).

This study same with research by Ratna Kristiyaningsih (2015) in Dukun Klopo Health center, Jombang Regency with Pvalue $=0.001$, it mean that there is a relationship between Family Support and the compliance of pregnant women trimester II and III to consume supplementation of Fe tablets regularly and as an effort to reduce the incidence of anemia in pregnant women.

\section{Conclusion}

There are relationship of mother's knowledge $($ Pvalue $=0,001)$ and Family Support (Pvalue $=$ 
$0,004)$ with anemia in pregnant women in the work area of Johan Pahlawan Sub-district in West Aceh Distirct with Pvalue $<\alpha=0.05$.

\section{Acknowledgement}

The researcher would like to thank the Head of the All person who helped during the data collection process in this study.

\section{Author Contribution and Competing Interest}

During the process of collecting, processing and analyzing data to the interpretation of all writers, they contributed and ensured that there were no conflicts of interest related to this text.

\section{Publisher's Note}

JONS : Jurnal Of Nutritien Science remains neutral with regard to jurisdictional claims in published institutional affilition.

\section{References}

Andarmoyo (2016). Analisis Faktor yang Berhubungan dengan Anemia Ibu Hamil di Kabupaten diari tahun 2015 (Tesis) Universitas Sumatera Utara. Ani, LS.2016. Buku Saku Anemia Defisiensi Besi.Jakarta; EGC.

Arisman. (2016). Gizi Dalam Daur Kehidupan. Jakarta: Penerbit Buku Kedokteran EGC.

Budiarto. (2014). Metodologi Penelitian Kedokteran: Sebuah Pengantar. EGC. Jakarta.

Dinkes Aceh. (2018). Profil Kesehatan Aceh tahun
2018. Aceh

Dinkes Aceh Barat. (2019). Profil Kesehatan Aceh Barat tahun 2019. Aceh Barat

Gibney. (2013_. Gizi Kesehatan Masyarakat. Jakarta: EGC.

Indah Lisfi. (2017). Hubungan Asupan $\mathrm{Fe}$ dan Vitamin A dengan Kejadian Anemia pada Ibu Hamil trimester III di Puskesmas air dingin kota padang. Andalas. Bursa Ilmu

Kemenkes RI. (2014). Pedoman gizi seimbang. Jakarta: Publikasi Data danInformasi Kemenkes RI

Kristiyana Sari. (2014). Gizi Ibu Hamil. Yogyakarta: Nuha Medika.

Manuaba, C, (2014). Ilmu Kebidanan, Penyakit Kandungan dan KB. Edisi 2. Jakarta: EGC

Nila Eza Fitria. (2017). Hubungan Pengetahuan Ibu Hamil tentang Tablet $\mathrm{Fe}$ dengan Kejadian Anemia. STIKes Ceria Buana

Notoadmodjo, S. (2014). Metodologi Penelitian Kesehatan. Jakarta: Rineka Cipta. Proverawati dan Asfuah. (2016). Buku Ajar Gizi untuk Kebidanan. Yogyakarta: Nuha Medika.

Sinaga E. S . (2015). Hubungan Pengetahuan Sikap dan Tindakan Pencegahan dengan Kejadian Anemia pada Ibu Hamil Trimester III yang Berkunjung ke Puskesmas Medan Deli tahun 2015. Skripsi: Medan.

Siregar. (2010). Sikap Kepatuhan dalam Tindakan.Jakarta: MITRA MEDIA. Siswanto, Susila, Suyanto. 2014. Metodologi penelitian kesehatan dan kedokteran. Yogyakarta: Bursa Ilmu.

Sulistyoningsih, H. (2016). Gizi untuk Kesehatan Ibu dan Anak. Yogyakarta: Graha Ilmu.

Supariasa, I, D, N., Bakri, B., \& Fajar, I. (2012). Penilaian status gizi. Jakarta: EGC. 